\title{
Assessment of Water Supply and Sanitation: The Case of Embacho Town, Gidan Woreda, Northern Ethiopia
}

\author{
Mulatu Kassa* \\ Department of Water Resource Engineering and Management, Wollega University, Shambu Campus, \\ Post Box No: 38, Shambu, Ethiopia
}

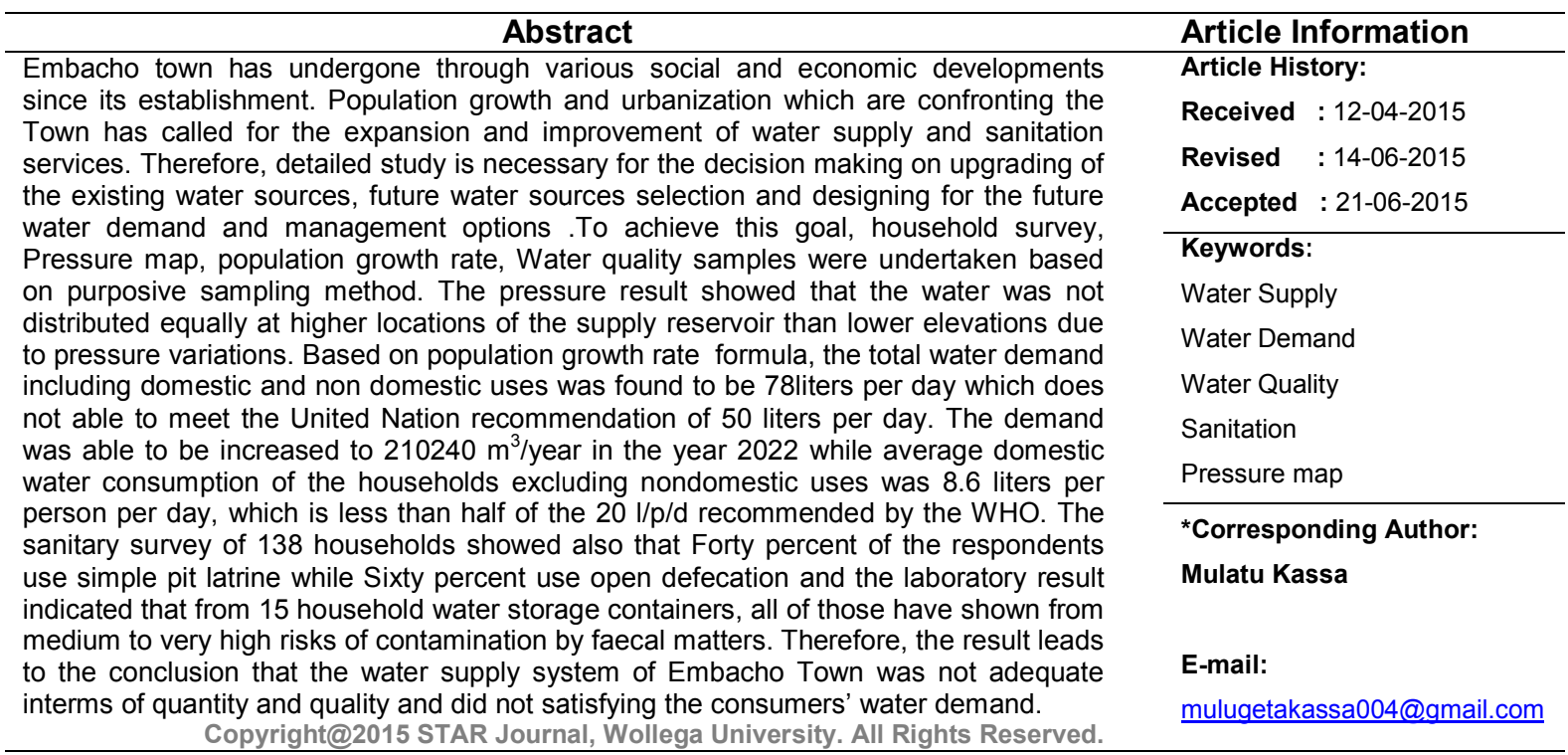

\section{INTRODUCTION}

Ethiopia is naturally endowed with abundant water resources that help to fulfill domestic requirements, irrigation and hydropower. Its current per-capita fresh water resources estimated at $1,924 \mathrm{~m}^{3}$ year ${ }^{-1}$ and the groundwater potential of the country is estimated to be 2.8 $\mathrm{BM}^{3}$ (Ethiopian Geological Survey, 2012).

Even if the country is endowed with abundant water sources, the problem of getting adequate and reliable water supply still is the most challenging issue of the country. The problems are exacerbated by high population growth and mushrooming Towns in Ethiopia. For instance, in 1984 there were 629 locations classified as Towns and by 2000 the number had increased to 925 , all in need of water supply and sanitation services (Birhan, 2011).

The UNICEF (2012) stated the coverage of water in Ethiopia to be $64.2 \%$ for country level, $61.8 \%$ for rural and $90.4 \%$ for urban. The MoWR (2008) stated that water coverage of Amhara region is $69.31 \%$ and the per capita per day water consumption ranged from 3 to 20 liters with median of 8.5 liters. Several studies have aso confirmed that water-related disease is expanding and the incidence of water-related microbial diseases is increasing (WHO, 2003). Diarrhea remains a major killer in children and it is estimated that $80 \%$ of all illness in developing countries is related to water and sanitation (WHO, 2004). Ministry of Health of Ethiopia estimated that 6000 children die each day from diarrhea (FDRE, 2004). Amhara region especially northern part of Ethiopia is not out of this reality. This study was conducted in Embacho Town, Gidan Woreda, Amhara Regional State in which accessibility to potable water and basic sanitation is the biggest challenge which negatively impacting the economic, environmental and social condition of people and still are untouched and unsolved problems. Therefore, this research work was aimed to examine the existing water supply and sanitation status and predict the water demand for the next ten years.

\section{MATERIALS AND METHODS}

\section{Description of the Study Area}

Embacho Town is located in Gidan woreda, North Wolo Zone of Amhara Regional State which was 
established in 1955 previously known as Aregash Ketema. It is located at a distance of about $581 \mathrm{~km}$ from Addis Ababa; $360 \mathrm{~km}$ from the regional capital of Bahir Dar; and about $180 \mathrm{~km}$ from the tourist attraction site, Lalibella (Figure 1).

The area under study has an average altitude of 2921 meters above sea level. The total population number of the Town is 6585 in the year 2012 with a total number of 850 with 4 persons per households (ANRSPB, 2010).

Spring water is the major source of Embacho Town. The current water source of pipe water system is supplied only from Rufael spring water. Water from Rufael spring is supplied through the pipe to the reservoir by gravity. The Town is geographically located between $12^{0} 55^{\prime} 49^{\prime \prime} \mathrm{N}$ $13^{0} 56$ ' $87^{\prime \prime} \mathrm{N}$ and $39^{\circ} 21^{\prime} 17^{\prime \prime} \mathrm{E}-39^{\circ} 24^{\prime} 17^{\prime \prime} \mathrm{E}$.

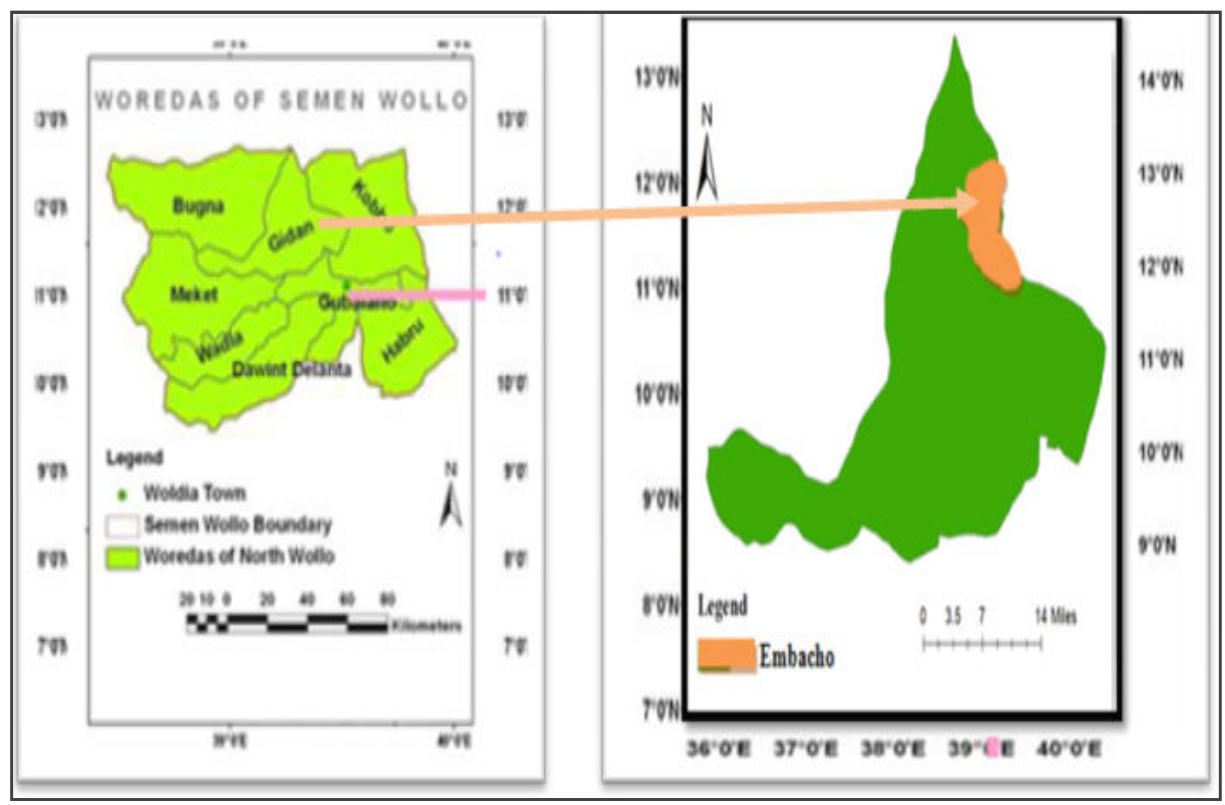

Figure 1: Location map of the study area

\section{Type and Sources of Data}

To get relevant information about qualitative and quantitative data both primary and secondary sources have been employed. The primary data about water use habit, existing sanitation condition, type of water source and the problems related with water quality were collected from, laboratory test, household survey, key informant interview, formal and informal discussions. Geographical positioning system (GPS) instrument was used to collect geographical coordinate data about, Reservoir, pipes and nodes which were missed from the water design map of the town.

Secondary data for quantitative study such as data about water pressure map, where demand and distribution system, location and pressure map, water source and discharge rate, and number of population description about the study area, location, topography, climate, population, and others data were collected from unpublished documents of Zone and District water offices.

\section{Method of Data Collection and Sampling Procedures Water Demand Projection}

The quantity of water supplied, the total volume of water consumed, water production data, development activities of the Town were all collected from GWWDB. Based on the, ten year's past data the existing and future water demand of Embacho Town were analyzed by using geometric growth rate method (Chatterjee, 2005; Abreham, 2011 and Bryman, 2008). The geometric growth method is given by,

$$
P=P_{o}\left(1+\frac{r}{100}\right)^{n}
$$

Where,

$\mathrm{P}=$ projected population

$\mathrm{P}_{0}=$ base population

$r=$ annual growth rate in percent

$\mathrm{n}=$ number of years (annual rate of growth)

\section{Water Quality Sampling Points}

To analyze the water quality in the laboratory, samples were taken from, water sources, main distribution systems, and sub-main distribution systems and from household water containers. Out of the six spring water sources, samples were taken from two sources $(n=2)$, reservoir $(n=1)$, tap $(n=4)$ and household water containers $(n=15)$. Therefore, a total of 22 water samples were considered for physico-Chemical and bacteriological examination. The samples were purposely five Small Kebeles called "GOTs" based on the current water supply sources and their geographical location. Water samples were collected labeled and transported to the North Wolo Water Resource Development Microbiological Water Quality Laboratory. To transport the samples to the laboratory, sterile glass bottles in a cold box containing ice freezer packs were used.

\section{Data Analysis and Presentation}

The existing water distribution was analyzed by using EPANET-2 SOFTWARE and to generate the pressure map SURFER-8 SOFTWARE was applied. 
The location of sampling points was analyzed by Arc map 10.1 GIS SOFTWARE. Analysis of variance (ANOVA) was used to test the average counts of physicochemical and bacteriological water quality parameters at $5 \%$ level of significance. LSD were used to identify among which water samples the significant is occurred. Pearson Correlation method was used to see the relationship between parameters at $1 \%$ significance level. Qualitative data collected from community, technical staff members, and water committees using questionnaire interviews and discussions were entered and analyzed in Statistical Package for Social Science (SPSS version 16.0). The data were presented using tables, percentages, graphs and mean values.

\section{RESULTS AND DISCUSSION}

The blue colour (Figure 2) at node 17 indicated Negative pressure value $(-2.02 \mathrm{~m})$ which does not meet the standard water pressure of $>15 \mathrm{~m}$ (MoWR, 2006). This indicated that water is not adequately reaching to the households at those water supply points. The pressure map (Figure3) proved that more satisfactory pressure is produced at lower elevations while low water pressure is generated at relatively higher locations.

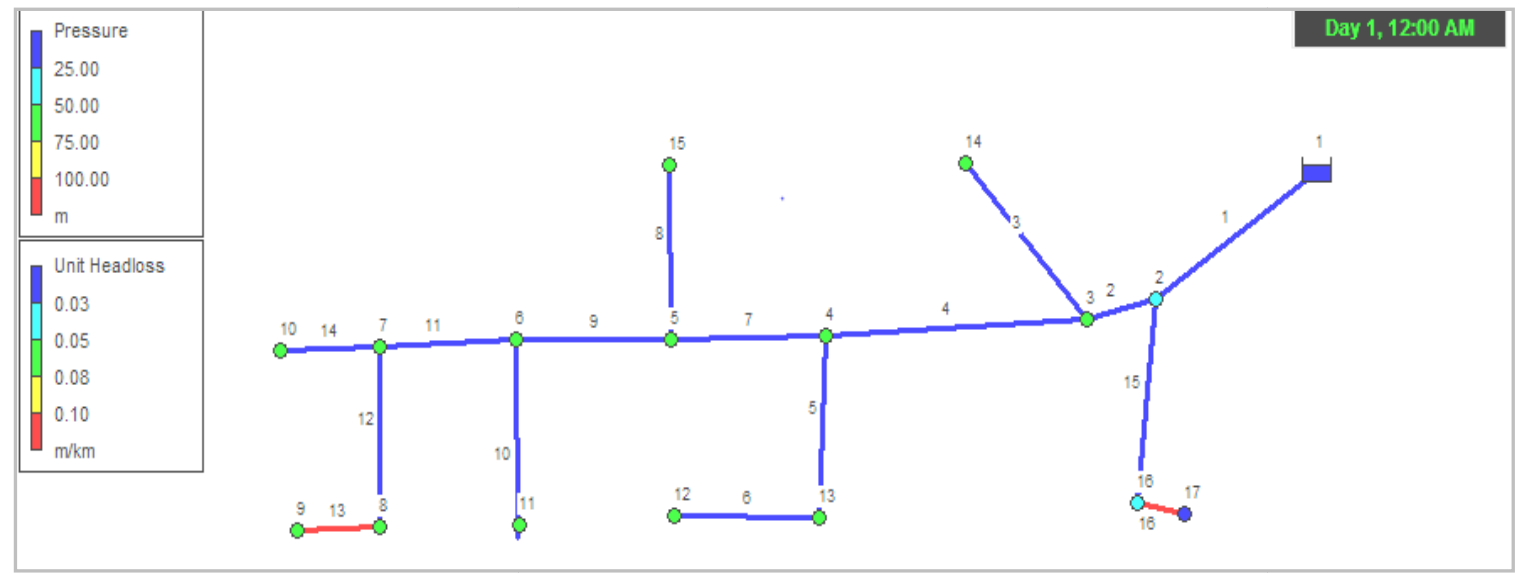

Figure 2: Water distribution network, EPANET result

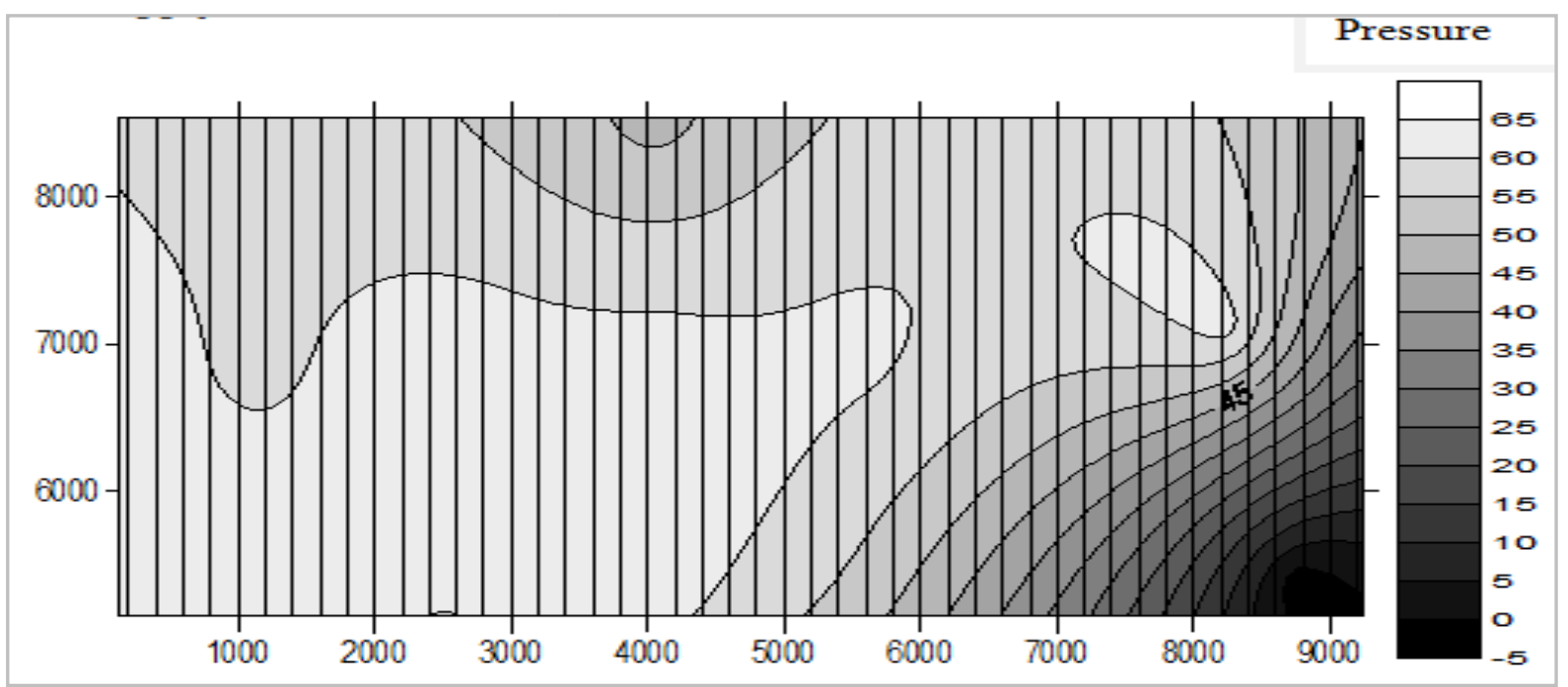

Figure 3: Pressure map, SURFER-output

When the height of the reservoir increased by $4 \mathrm{~m}$ (from $2870 \mathrm{~m}$ to $2874 \mathrm{~m}$ ), the distribution network indicates pressure between $15 \mathrm{~m}$ and $70 \mathrm{~m}$ and the negative pressure $(-2.02 \mathrm{~m})$ was improved to $(15.63 \mathrm{~m})$ which is satisfactory pressure to supply water (Table 1$)$.

\section{Water Quality}

There were no significant difference of temperature and $\mathrm{PH}$ among all the water sources ( $\mathrm{F}$ calculated $<\mathrm{F}$ (ratio) tabulated, $P<0.05$ ). The increased TC and FC counts in stored water may be due to bacterial re-growth or recontamination of water through dipping with hands and stored water container. The presence of biofilm on the inner surfaces may also offer a suitable medium for contaminating good quality water.TC, FC and Turbidity were significant among water sources samples $(P<0.05)$. These might be because of lack of controlling temperature at disinfection points, which leads to the re-growth bacteria and no regular chlorination was adopted. The increased TC and FC counts in stored water may be due to bacterial re-growth or recontamination of water through dipping with hands and stored water container. The presence of Biofilm on the inner surfaces may also offer a suitable medium for contaminating good quality water (Table 1). 
Table 1: Water quality analyses results of sampled water sources

\begin{tabular}{lccccccc}
\hline \multicolumn{1}{c}{ Parameters } & $\begin{array}{c}\text { Zewudu } \\
\text { Spring }\end{array}$ & $\begin{array}{c}\text { Rufael } \\
\text { Spring }\end{array}$ & $\begin{array}{c}\text { Disinfection } \\
\text { point }\end{array}$ & $\begin{array}{c}\text { Tap } \\
\text { waters }\end{array}$ & Containers & $\begin{array}{c}\text { WHO } \\
\text { Guide line }\end{array}$ & $\begin{array}{c}\text { Ethiopian } \\
\text { Standard }\end{array}$ \\
\hline Temp $\left({ }^{\circ} \mathrm{C}\right)$ & $20.1 \pm$ & $18.45 \pm$ & $19.4 \pm$ & $20.2 \pm$ & 23.9 & $<15$ & $<15$ \\
Turb $(\mathrm{NTU})$ & $7.5 \pm$ & $2.71 \pm$ & $1.02 \pm$ & $1.2 \pm$ & 3.4 & $<5$ & $<7$ \\
$\mathrm{PH}$ & $6.95 \pm$ & $7.3 \pm$ & $7.0 \pm$ & $8.2 \pm$ & 6.59 & $6.5-8.5$ & \\
Fluoride $(\mathrm{mg} / \mathrm{l})$ & 0 & 0 & 0 & 0 & 0 & $<1.5$ & \\
TC cfu/100ml & $15 \pm$ & 0 & 0 & 0 & 46 & $<10$ & \\
FC cfu/100ml & $11 \pm$ & 0 & 0 & 0 & 34 & $0 / 100$ & $0.2-0.5$ \\
FCR $(\mathrm{mg} / \mathrm{l})$ & 0 & 0 & 0.01 & 0 & 0 & $0.2-0.5$ & 0.5 \\
\hline
\end{tabular}

\section{Water Demand Projection}

The projected total water demand will increase by 108 $\mathrm{m}^{3} /$ day from 2012 to 2017 and it will be increased by 168 $\mathrm{m}^{3} /$ day during 2017 to 2022 period. In order to reach the water supply coverage of the Town at least $75 \%$ by 2022 , the water supply should be $157680 \mathrm{~m}^{3} /$ year (Figure 4).

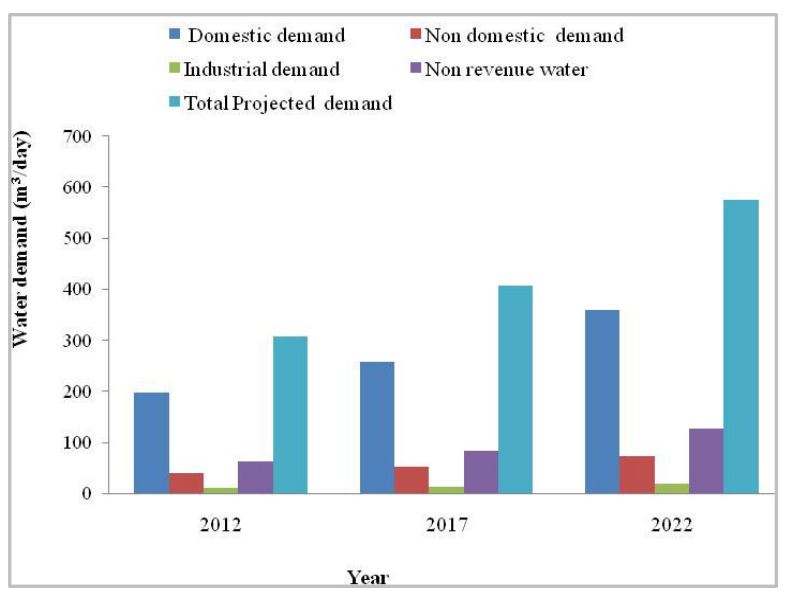

Figure Error! No text of specified style in document.: projections of water demand by category (2022)

\section{Water and Sanitation Accessibility}

With regarded to sanitation, $40 \%$ of the respondents use simple pit latrine, these is due to the enforcement of health extension workers, $60 \%$ of the respondents use open defecation. Public toilets and privet toilets are common in the study area. About 30 people use in one common public toilet. Three types of latrines were constructed in the study area. Pit latrine with closed wall and roof, Open pit latrine/without house and Pit latrine with walls but without roof. All the latrines were not clean and safe for defecation aggravated by water supply service problems. Water for hygienic activities like wash their hands $(65 \%)$, washing of clothes $(79 \%)$, washing of body $(66 \%)$, washing their children's body $(24 \%)$, washing their children's hand $(11 \%)$ and $10 \%$ washing utensils and washing hands after defecating $(0.2 \%)$ but $70 \%$ wash hands after defecation. More than $50 \%$ of respondents were neither using soap nor ash for hand washing.

\section{CONCLUSION}

The result of this work showed that the water supply system of Embacho Town has now serious problem to give satisfactory service to the community. Topographic variation and pipe damages were the underlined causes for inadequacy of water pressure to supply the required demand at the current condition. Therefore, exploration/searching of new water sources and increasing the water supply efficiency are necessary engagements of concerned bodies and voluntary service providers to minimize the problem.

The total coli form and Faecal coliforms counts were higher in household water samples compared to that of tap water. High counts of total coliform and faecal coliform at the house hold drinking water indicates that the water has been faecal contaminated. Poor sanitation and poor hygiene in household were the main factors for the contamination water during transportation and after storage at home. The average per capita domestic water consumption of more than $75 \%$ of the sample households is less than $20 \mathrm{l} / \mathrm{c} / \mathrm{d}$. Compared to WHO standard for basic access $(20 \mathrm{l} / \mathrm{c} / \mathrm{d})$, this is low.

\section{Acknowledgements}

First and for most, my sincere and deepest thanks goes to my academic advisor Dr. Brook Abate for his constructive comments, valuable advices and unreserved assistance from the inception of research proposal to the write up of the final work. My special thanks go to the manager of Gidan Woreda Water Development Bureau.

\section{Conflict of Interest}

Conflict of interest none declared.

\section{REFERENCES}

Abreham M. (2011). Water Supply and Demand Analysis of Hawassa Town: M.Sc. Thesis (Unpublished), Hawassa University.

Birhan, A. (2011). Causes and Consequences of Rural-Urban Migration: The case of Woldiya Town, North Ethiopia, Master of Arts, Thesis, University of South Africa.

Chatterjee, A. K. (2005). Water Supply, Water Disposal and Environmental Engineering. Khanna publishers, Nai Sarak, Delhi-110006. 